\title{
Meteorological controls on glacier mass balance in High Asia
}

\author{
L.A. RASMUSSEN \\ Department of Earth and Space Sciences, University of Washington, Seattle, WA, USA \\ E-mail: lar@ess.washington.edu
}

\begin{abstract}
The aim of this study is to investigate spatial and temporal variations of meteorological variables known to control glacier mass-balance processes, and to demonstrate their relevance in High Asia. The study uses the NCEP/NCAR reanalysis database (US National Centers for Environmental Prediction and US National Center for Atmospheric Research), which is global and continuous since 1 January 1948. A positive degree-day (PDD) model of annual glacier-wide summer surface balance, $B_{s}$, uses upper-air temperatures at NCEP/NCAR gridpoints near each of six glaciers between 40 and $45^{\circ} \mathrm{N}$ and between 71 and $87^{\circ} \mathrm{E}$ and two others near $50^{\circ} \mathrm{N}, 87^{\circ} \mathrm{E}$. Model error ranged between 0.19 and $0.41 \mathrm{~m}$ w.e., comparable with the observational accuracy of $B_{\mathrm{s}}$. Sensitivity to temperature change, $\mathrm{d} B_{\mathrm{s}} / \mathrm{d} T$, ranges between -0.5 and $-0.2 \mathrm{~m}$ w.e. $\mathrm{a}^{-1}{ }^{\circ} \mathrm{C}^{-1}$ for these glaciers.
\end{abstract}

\section{INTRODUCTION}

The extent of glaciers in the mountainous region of all of Asia, including the former USSR $\left(\sim 128000 \mathrm{~km}^{2}\right.$; Hirabayashi and others, 2010), is the third largest on Earth, after the Arctic-Greenland and Antarctic regions. Half or more of summer streamflow in major rivers in High Asia is from glacier melt (Barnett and others, 2005), which is particularly important for the Indus and Brahmaputra Rivers and less so for the other major rivers of Asia (Immerzeel and others, 2010). Most crucial is the glacier influence on the rivers in the Aral Basin (Kaser and others, 2010).

A related potential impact of glacier mass change is on the oceans. Contribution to recent sea-level rise by glaciers in this region, however, has been slight because their rate of thinning is relatively small compared with glaciers elsewhere (Jacob and others, 2012). Moreover, some glaciers in the region, particularly in the Karakoram, have not lost mass over recent decades and some have even gained mass (Hewitt, 2005; Bolch and others, 2012; Gardelle and others, 2012). Mass balance of glaciers in most of High Asia, however, has been becoming more negative (WGMS, 2008a).

Apart from effects of long-term changes in their mass, glaciers exert a significant influence on the seasonal variation of streamflow. They store water in years of high snowfall and release it in years of low snowfall, thus moderating interannual variation of streamflow. They also provide streamflow later in the summer, after seasonal snow has melted, which is the period of high demand for agriculture, hydropower and domestic consumption (Barnett and others, 2005). Delay of flow is caused by temporary englacial storage of spring meltwater and by peak meltwater production occurring in midsummer (Fountain and Tangborn, 1985). There is insufficient reservoir capacity in the western part of high-mountain Asia to accommodate the shift in the seasonal cycle by storing early-season melt until it is needed (Barnett and others, 2005). In the eastern part, under the influence of the South Asia monsoon, by contrast, snowfall and subsequent snowmelt occur during the period of need.

The shortage of published measurements of surface mass balance in the region (Cogley, 2011; Bolch and others, 2012) hampers calibration of mass-balance models for glaciers there. Of the few mass-balance programs that existed, many have been discontinued since the collapse of the USSR (WGMS, 2008a). Most remaining monitoring programs are glacier inventories obtained by remote sensing. As well as giving glacier extent, they also provide multiyear change in glacier thickness (Berthier and others, 2007; Bolch and others, 2011), which is closely related to cumulative mass balance over the period between surveys.

Although there is a relative abundance of measurements of change of glacier area and length in the region, such changes are not related to meteorological conditions in a simple way. Change of glacier area is a complicated, nonlinear function of mass balance over a large number of preceding years (Kargel and others, 2011). Annual mass balance, by contrast, is a direct, immediate effect of the year's meteorological conditions. Meteorological variables known to provide a good basis for models of mass balance, especially of summer surface balance (e.g. Rasmussen and Conway, 2003), are available from 1 January 1948 in the NCEP/NCAR reanalysis database (US National Centers for Environmental Prediction and US National Center for Atmospheric Research; Kalnay and others, 1996; Kistler and others, 2001). It is useful, therefore, to consider spatial and temporal variation of those variables in the region since then.

\section{METHODS}

Precipitation from the reanalysis database is averaged over 1948-2010 for both winter and summer, and each of these is contoured over $25-50^{\circ} \mathrm{N}, 60-100^{\circ} \mathrm{E}$. Insight into the spatial variation of its seasonality is provided by the mean 19482010 monthly wind vector at $600 \mathrm{hPa}$ ( $4300 \mathrm{~m}$ a.s.l.), which is an indication of advection of moisture from marine sources, at four selected locations. Temporal variation of annual precipitation at each location is analyzed by fitting a piecewise-constant function; stages of the function are chosen empirically, so that the probability that the values in two successive stages are from the same population is small according to Student's $t$-test.

The same piecewise-constant analysis is applied to temperature at each location in the form of the number of annual positive degree-days, PDD, at altitudes representative of the nearby glaciers. Covariance of mean 19482010 monthly temperature and precipitation at each location is demonstrated by plotting them jointly rather than as two separate monthly series. 
Table 1. Positive degree-day (PDD) model results. Recorded statistics of glacier-wide summer surface balance, $B_{\mathrm{s}}$, its mean, $\bar{B}_{\mathrm{s}}$, and standard deviation, $\sigma_{B_{\mathrm{s}}}$, with the rms model error of $B_{\mathrm{s}}^{*}-B_{\mathrm{s}}$ (Eqn (1)). Observed balance, $B_{\mathrm{s}}$, from WGMS (2008b) and previous issues of Fluctuations of glaciers. The PDD factor is $\alpha$, and sensitivity to $+1^{\circ} \mathrm{C}$ temperature change is $\Delta B_{\mathrm{s}}$. Letters indicate glacier locations (Figs 1 and 2 ). Glaciers $A$ and $G$ are in Kyrgyzstan, $T$ and $S$ in Kazakhstan, $U$ in China and $M$ in Russia

\begin{tabular}{|c|c|c|c|c|c|c|c|c|}
\hline Glacier & $\begin{array}{l}\text { Altitude } \\
\text { ma.s.l. }\end{array}$ & $\begin{array}{c}\bar{B}_{\mathrm{s}} \\
\mathrm{m} \text { w.e. }\end{array}$ & $\begin{array}{c}\sigma_{B_{\mathrm{s}}} \\
\mathrm{m} \text { w.e. }\end{array}$ & Period & $z^{\prime}$ & $\begin{array}{c}\text { rms } \\
\text { mw.e. }\end{array}$ & $\begin{array}{c}\alpha \\
\mathrm{mm} \text { w.e. }\left(\mathrm{d}^{\circ} \mathrm{C}\right)^{-1}\end{array}$ & $\begin{array}{c}\Delta B_{\mathrm{s}} \\
\text { m w.e. }\end{array}$ \\
\hline A Abramov & $3650-4650$ & -1.82 & 0.41 & 1986-98 & 4150 & 0.23 & -5.1 & -0.47 \\
\hline G Golubin & $3275-4325$ & -1.01 & 0.25 & $1981-94$ & 3775 & 0.21 & -1.6 & -0.17 \\
\hline T Ts. Tuyuksu & $3450-4160$ & -1.29 & 0.44 & 1965-2000 & 3850 & 0.36 & -3.7 & -0.40 \\
\hline S Shumskiy & $3050-4410$ & -1.13 & 0.42 & 1968-91 & 3350 & 0.41 & -1.3 & -0.17 \\
\hline U Ürümqi E & $3750-4220$ & -0.60 & 0.32 & 1989-2007 & 4000 & 0.21 & -4.4 & -0.45 \\
\hline U Ürümqi W & $3800-4450$ & -0.50 & 0.30 & 1989-2007 & 4100 & 0.24 & -3.9 & -0.35 \\
\hline M Leviy Aktru & $2650-3950$ & -0.77 & 0.28 & 1981-2000 & 3300 & 0.19 & -4.0 & -0.31 \\
\hline M Maliy Aktru & $2250-3650$ & -0.72 & 0.29 & 1976-2005 & 3000 & 0.23 & -2.8 & -0.30 \\
\hline
\end{tabular}

The PDD is widely used to estimate summer surface balance (Braithwaite, 1981; Ohmura, 2001; Hock, 2003). A simple model

$$
B_{\mathrm{s}}^{*}=\alpha T^{+}\left(z^{\prime}\right)+\beta
$$

interpolates linearly in the upper-air temperature profile $T(z)$ at the NCEP/NCAR gridpoint nearest the glacier. Here $T^{+}\left(z^{\prime}\right)$ is the PDD and $z^{\prime}$ is the middle of the glacier's altitude range. Coefficients of the linear regression, $\alpha$ and $\beta$, are determined separately for each glacier to minimize the root-mean-square (rms) difference between $B_{\mathrm{s}}^{*}$ and observed balance, $B_{\mathrm{s}}$, calculated over the glacier's period of record. In the absence of published observation dates for each year, the summation of $T^{+}\left(z^{\prime}\right)$ is conducted over the entire calendar year, relying on the fact that most temperatures outside the ablation season are negative and thus have little effect on the sum.

For glaciers for which annual records do not exist, published geodetic determinations of mean multi-year annual surface balance, $B_{\mathrm{a}}$, are compared qualitatively with PDD sums and with precipitation, both averaged over the same multi-year period.

\section{DATA SOURCES}

The NCEP/NCAR reanalysis database is available globally from Columbia University, with daily records since 1 January
1948, at http://iridl.Ideo.columbia.edu/SOURCES/.NOAA/. NCEP-NCAR/.CDAS-1/.DAILY Temperature and wind are given at many levels in the atmosphere at integer multiples of $2.5^{\circ}$ in both latitude and longitude spanning the entire globe. Precipitation is given at a similar array of points.

The World Glacier Monitoring Service (WGMS, 2008b) publishes annual measurements of seasonal surface mass balance, including summer balance for eight glaciers in the region (Table 1 ; Fig. 1 ).

Cogley (2008) gives mean annual surface mass balance, $B_{a}$ (Table 2), for eight glaciers near each other in the Tien Shan for two multi-year periods. Fujita and Nuimura (2011) present geodetic determinations from several sources for Rikha Samba, Yala and AX010 glaciers, as do Han and others (2006) for Ürümqi glacier No. 1 (Table 3). For seven other glaciers, near Qomolongma (Mount Everest) (Table 3), Bolch and others (2011) obtained multi-year (geodetic) mass balances from repeat satellite imagery.

\section{RESULTS}

Analysis here is confined to describing the temporal/spatial variation of data from the NCEP/NCAR reanalysis, particularly precipitation and upper-air temperature. Although there are several weather stations in the region, it is not a trivial task to construct a spatially comprehensive description of

Table 2. 1973 shift in glacier-wide mean surface annual mass balance, $\bar{B}_{\mathrm{a}}$. The probability that the $\bar{B}_{\mathrm{a}}$ values (Cogley, 2008) in the two periods are from the same population is $p<0.02$ for glaciers 6 and $8, p<0.01$ for the others. Location (Tien Shan) is indicated by T in Figures 1 and 2 . The values in the bottom three rows are PDD and the nearby precipitation, $P(\mathrm{~m})$

\begin{tabular}{|c|c|c|c|c|}
\hline Glacier & $\begin{array}{l}\text { Latitude } \\
{ }^{\circ} \mathrm{N}\end{array}$ & $\begin{array}{l}\text { Longitude } \\
{ }^{\circ} \mathrm{E}\end{array}$ & $\begin{array}{c}\text { 1965-73 mean } \\
\text { m w.e. } a^{-1}\end{array}$ & $\begin{array}{c}\text { 1974-90 mean } \\
\text { m w.e. } \mathrm{a}^{-1}\end{array}$ \\
\hline 1 Ts. Tuyuksu & 43.01 & 77.12 & -0.14 & -0.61 \\
\hline 2 Kosmodemyanskoy & 43.02 & 77.10 & +0.08 & -0.38 \\
\hline 3 Mametova & 43.04 & 77.10 & -0.14 & -0.60 \\
\hline 4 Mayakovskiy & 43.02 & 77.11 & +0.16 & -0.25 \\
\hline 5 Molodezhniy & 43.01 & 77.09 & -0.14 & -0.80 \\
\hline 6 Ordzhonikidze & 43.03 & 77.12 & +0.02 & -0.27 \\
\hline 7 Partizan & 43.03 & 77.08 & +0.52 & +0.12 \\
\hline 8 Visyachiy & 43.03 & 77.08 & -0.21 & -0.45 \\
\hline $3500 \mathrm{~m}$ annual PDD & 42.50 & 77.50 & 648 & 699 \\
\hline Oct-Sept $P$ & 42.85 & 76.88 & 235 & 191 \\
\hline May-Sept $P$ & 42.85 & 76.88 & 125 & 111 \\
\hline
\end{tabular}




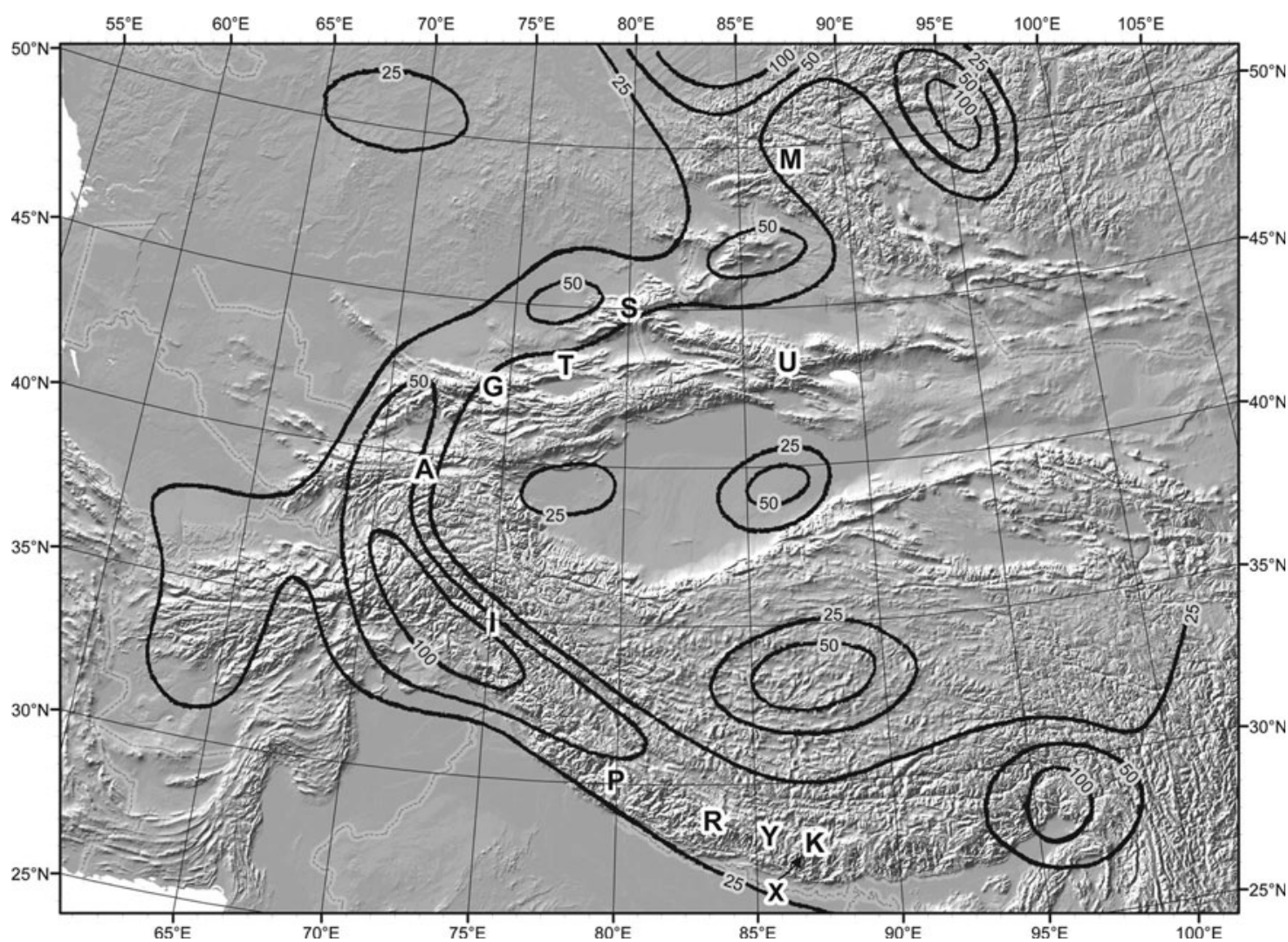

Fig. 1. Mean 1948-2010 October-April precipitation (cm). A, G, M, S, T, U show locations of glaciers in the Tien Shan (Table 1); R, Y, X, K show glaciers in the eastern Himalaya (Table 3); I the Upper Indus basin in the western Himalaya, and P Pindari Glacier.

Table 3. Geodetic glacier-wide surface balance, $B_{\mathrm{a}}$ (m w.e. $\mathrm{a}^{-1}$ ). Balance values, $B_{\mathrm{a}}$, for $\mathrm{R}, \mathrm{Y}, \mathrm{X}$ from Fujita and Nuimura (2011), for $\mathrm{U}$ from Han and others (2006), for the others from Bolch and others (2011). $P$ is May-September precipitation (mw.e.) All are in the eastern Himalaya except for Ürümqi, which is in the Tien Shan

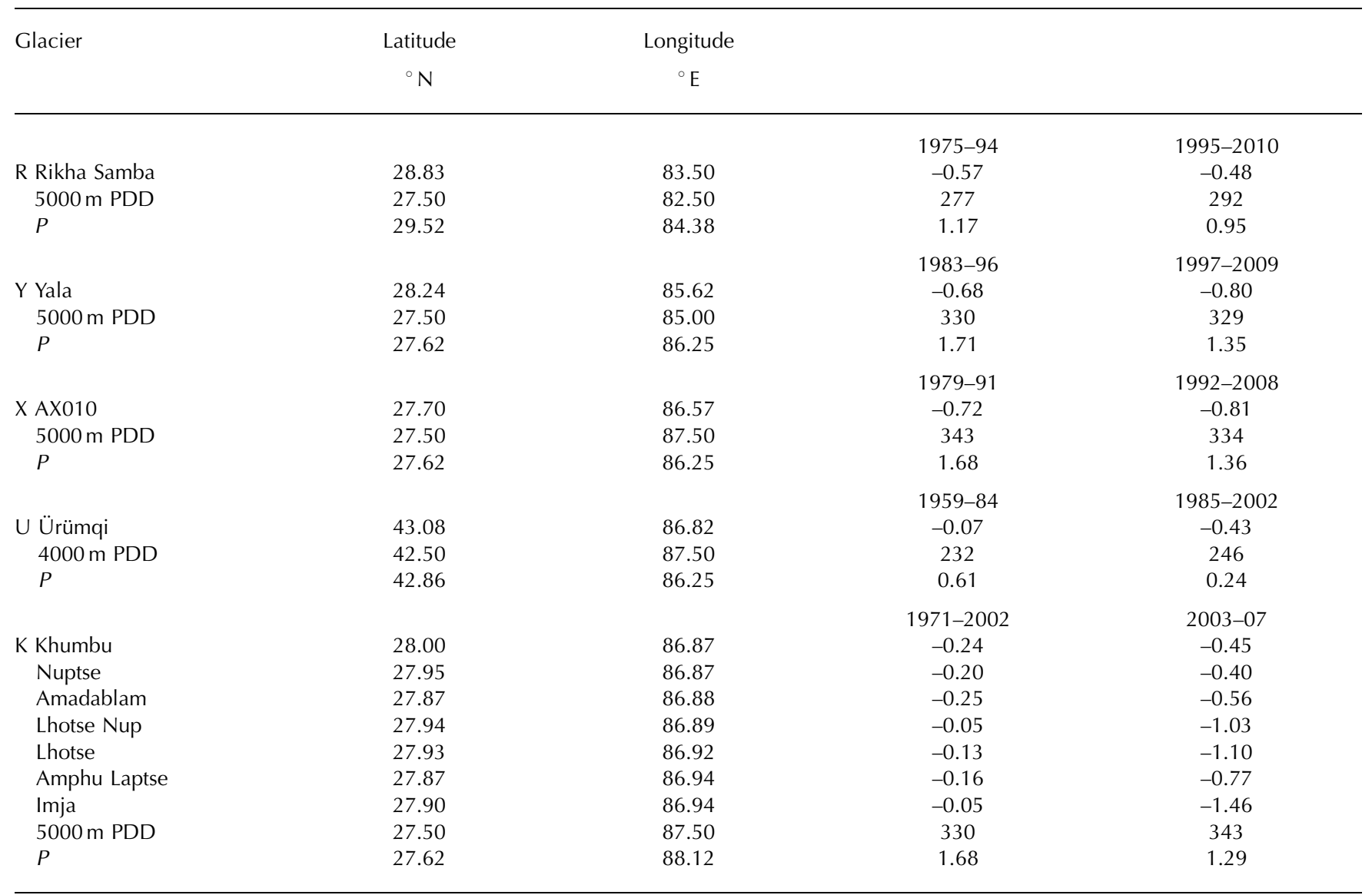




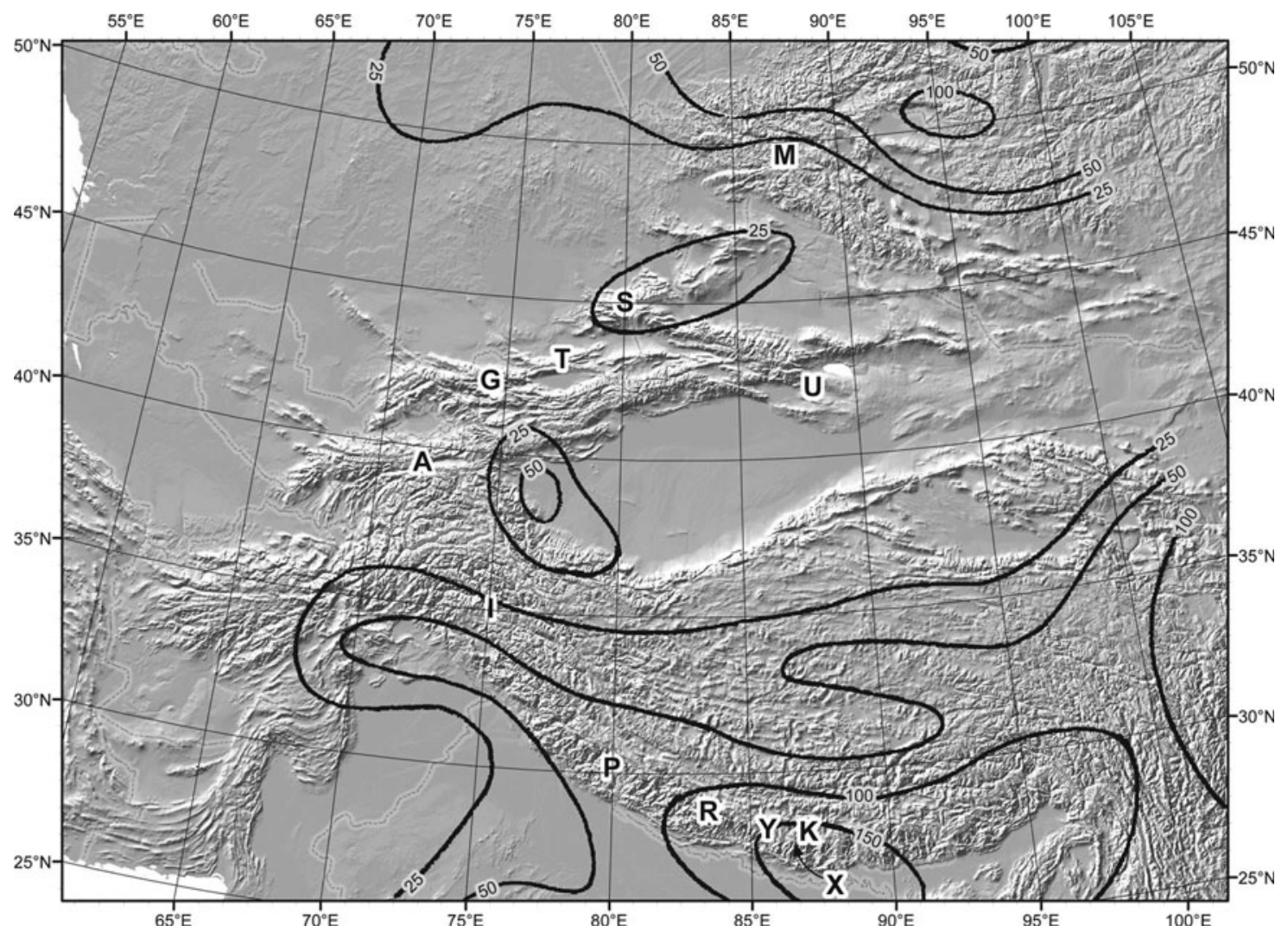

Fig. 2. Mean 1948-2010 May-September precipitation (cm). A, G, M, S, T, U show locations of glaciers in the Tien Shan (Table 1); $R, Y, X, K$ show glaciers in the eastern Himalaya (Table 3); I the Upper Indus basin in the western Himalaya; and P Pindari Glacier.

meteorological conditions from them that is relevant to glacier mass balance. Nevertheless, excellent analyses of meteorological conditions in particular subregions have been published. Among these are Aizen and others (1997) and Bolch (2007) for the Tien Shan, Frauenfeld and others (2005) for the Tibetan Plateau, Bolch and others (2012) for the Himalaya, and Shrestha and others (2000) for Nepal.

Utility of the upper-air temperature and the PDD model (Eqn (1)) is demonstrated for eight glaciers in the region. When driven with these data, the model gives errors (Table 1) that are of the order of observational accuracy. Kayastha and others (2003) found much larger $\alpha$ values for three glaciers in Nepal.

\section{Variation of precipitation}

Spatial variation over central Asia $\left(25-50^{\circ} \mathrm{N}, 60-100^{\circ} \mathrm{E}\right)$ of the mean 1948-2010 winter (October-April) and summer (May-September) precipitation shows a winter maximum in the western part of the region and a summer maximum in the southeastern part (Figs 1 and 2).

Annual precipitation has declined over that period at both ends of the Himalaya, but not in the Tien Shan. The coarse grid on which the NCAR/NCEP precipitation is supplied does not resolve smaller-scale features.

Temporal variation of precipitation over 1948-2010 is shown in Figure 3 at three points along the length of the Himalaya and one in the Tien Shan. Consistent with variation at the easternmost point are ice-core measurements from Rongbuk Glacier on Qomolongma by Ren and others (2006). They showed that annual accumulation decreased rapidly from the 1950 s to the 1960s, remained constant until the 1980s, then decreased again.
Glacier accumulation depends on the availability of moisture, which is advected by upper-air winds. Wind at $600 \mathrm{hPa}(\sim 4300 \mathrm{~m}$ a.s.l.) in the Tien Shan is strongly zonal throughout the entire year (Fig. 4a). Seasonal variation of wind direction is qualitatively similar between the middle of the Himalaya (Fig. 4c) and the eastern end (Fig. 4d), with a large variation of direction in summer. In the west (Fig. 4b), the mean wind is weakly westerly during October-April; in summer it veers to the northwest and weakens. In the east it is also westerly during October-April but is much stronger than in the west; in summer, during the monsoon, it becomes roughly southerly but weaker. In the middle of the Himalaya, the westerly wind in winter is weaker than in the east, and during the summer becomes southwesterly.

Correlation of winter surface balance, $B_{\mathrm{w}}$, with winter precipitation at the nearest NCEP/NCAR gridpoint on an annual basis was moderate for Abramov Glacier $(r=0.64$ over 13 years) and Golubin Glacier ( $r=0.48$ over 14 years), but was negligible at four other glaciers in the region. According to Rupper and Roe (2008), the 'magnitude of total precipitation and interannual ... variability in the Reanalysis output could be off by a factor of 2 or more'. Over multi-year periods, however, the correlation with geodetic balance over the same periods appears to be stronger (Tables 2 and 3).

\section{Variation of temperature}

In contrast to the east-west variation in precipitation trends, temperature at the mean altitude of the glaciers, expressed as the annual PDD, shows opposite trends at the two ends. It decreased between 1948-66 and 1967-2010 by 15\% in the west and increased by the same amount in the east. The 1948-2010 variation of annual PDD is shown in Figure 5 for 


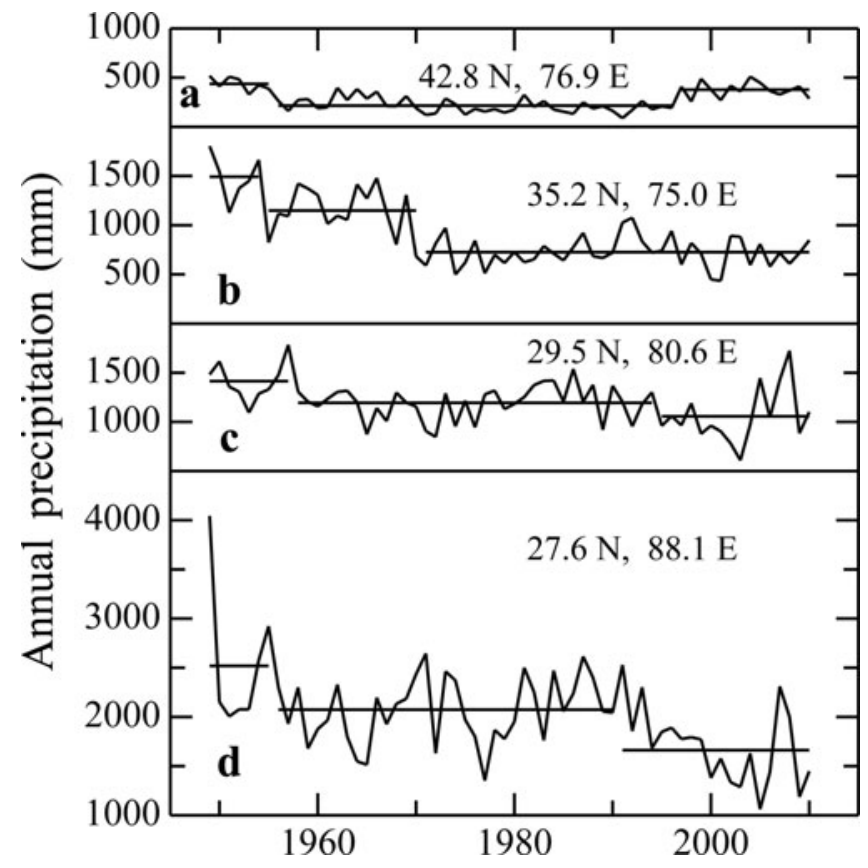

Fig. 3. 1948-2010 variation of annual precipitation, $P(\mathrm{~mm})$, at locations (a) T, (b) I, (c) P and (d) K, shown in Figures 1 and 2. Each series is fit with a piecewise-constant function, stages of which are determined empirically so the probability, $p$, that the values in two successive stages are from the same population is small according to Student's $t$-test. For all pairs of successive stages, $p<0.01$, except that $p=0.03$ for the 1994-95 shift in (c).

the same four locations in the region as in Figures 3 and 4. The striking feature is that the cooling after the mid-1960s in the west occurred at the same time as warming in the east. Fowler and Archer (2006) found $1{ }^{\circ} \mathrm{C}$ cooling in the west after 1961.

East-west variation in the Himalaya of the covariance between mean 1948-2010 mean monthly temperature near the middle of the altitude range of the glaciers and mean monthly precipitation (Fig. 6b-d) parallels east-west variation of the wind (Fig. 4), in that the monsoon regime dominates most of the Himalaya. Instead of the summer maximum of precipitation existing in that regime, the west has a winter maximum (Fig. 6b). In the Tien Shan (Fig. 6a) there is a spring maximum of precipitation.

Both the $4000 \mathrm{~m}$ annual PDD and the summer precipitation changed in 1984 at Ürümqi glacier No. 1, contributing to making annual surface balance, $B_{a}$, more negative (Table 3). Han and others (2006) found that $B_{\mathrm{a}}$ at Ürümqi glacier No. 1 declined from $-0.07 \mathrm{ma}^{-1}$ over 1959-84 to $-0.43 \mathrm{~m} \mathrm{a}^{-1}$ over $1985-2002$ to $-0.74 \mathrm{ma}^{-1}$ over 1997-2002. Differencing the last two values yields $B_{\text {a }}$ over 1985-96 of $-0.28 \mathrm{ma}^{-1}$, indicating increasingly negative values over the three subperiods during 1959-2002.

\section{DISCUSSION}

Spatial and temporal variations of precipitation have received much attention in the literature, which gives valuable insight into the large-scale synoptic conditions underlying the variations shown here (Figs 1-3). In concentrating on some smaller subregions, the literature also furnishes greater detail, for temperature as well as precipitation, than the coarse NCEP/NCAR data.

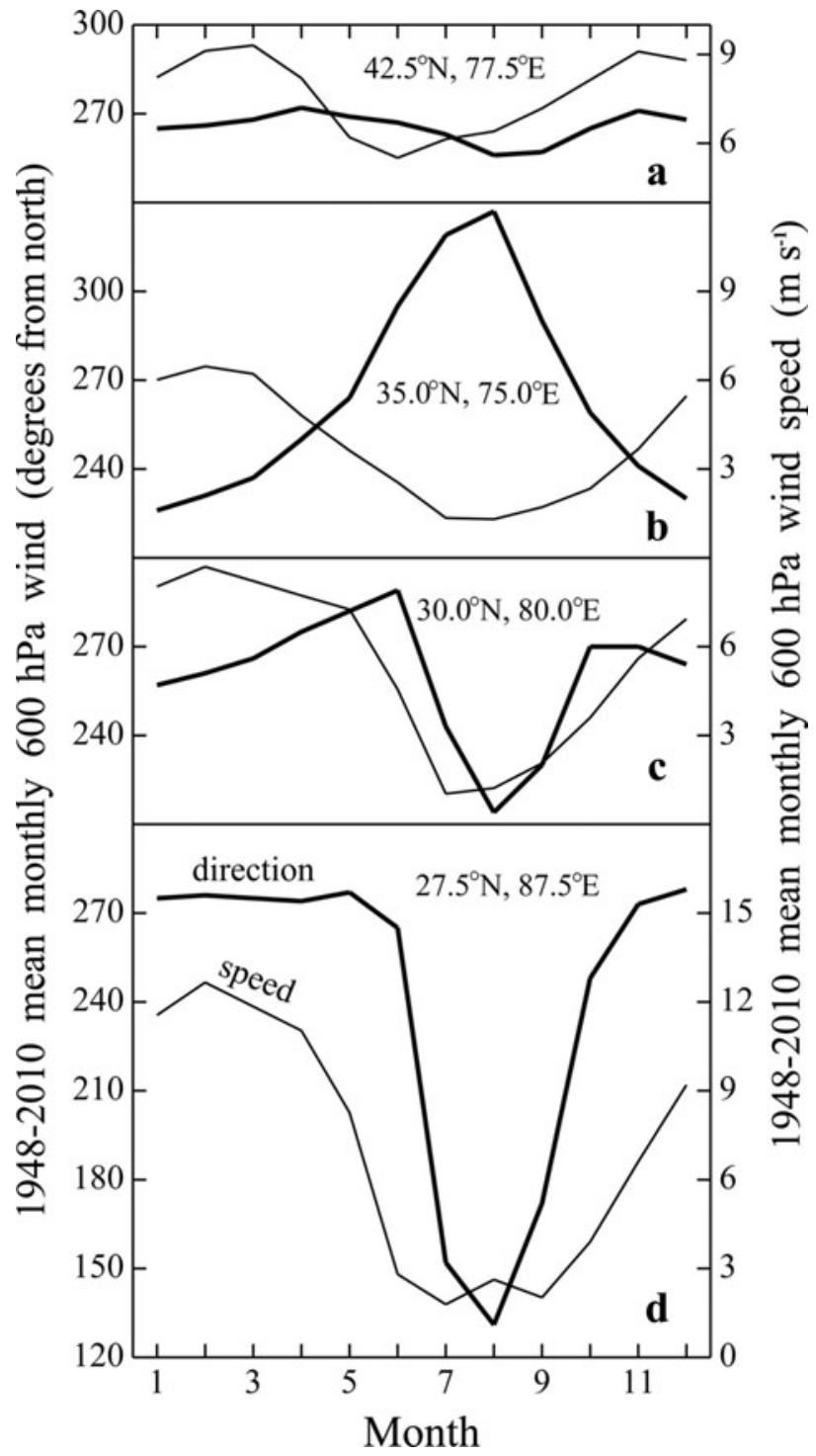

Fig. 4. Mean seasonal variation, $1948-2010$, of $600 \mathrm{hPa}(\sim 4300 \mathrm{~m}$ a.s.l.) wind, $\vec{V}$, at locations (a) T, (b) I, (c) P and (d) $\mathrm{K}$ shown in Figures 1 and 2. Direction (heavy curve) and speed (light curve) are shown at monthly resolution.

Storms in the western part of the region (Thayyen and Gergan, 2010) are centered at $\sim 500 \mathrm{hPa}(\sim 5500 \mathrm{~m}$ a.s.l. $)$, southerly monsoons at $\sim 850 \mathrm{hPa}(\sim 1500 \mathrm{~m}$ a.s.l.). In the Karakoram Himalaya $\left(\sim 77^{\circ} \mathrm{E}\right)$, there are an average of 40 to 50 extratropical storms from the west each year, persisting 2-4 days (Bhutiyani, 1999). Precipitation at Ürümqi glacier No. 1 has a summer maximum (Jing and others, 2006). Shrestha and others (2000) show large interannual and decadal variation in Nepal precipitation and found moderately positive correlation between it and the Southern Oscillation Index (SOI) but none with either the quasibiennial oscillation $(\mathrm{QBO})$ or the sunspot cycle.

Putkonen (2004) found that near Annapurna, in central Nepal, during 1999-2001 the maximum precipitation occurred at $\sim 3000 \mathrm{~m}$. Bookhagen and Burbank (2010) found that along a south-north transect in the central Himalaya there is a double maximum, a smaller one south of the larger one, but there is a single maximum in the west and in the east. The start of the monsoon varies from year to year, but is always within about 10 days of 1 June (Pai and Rajeevan, 2007). 


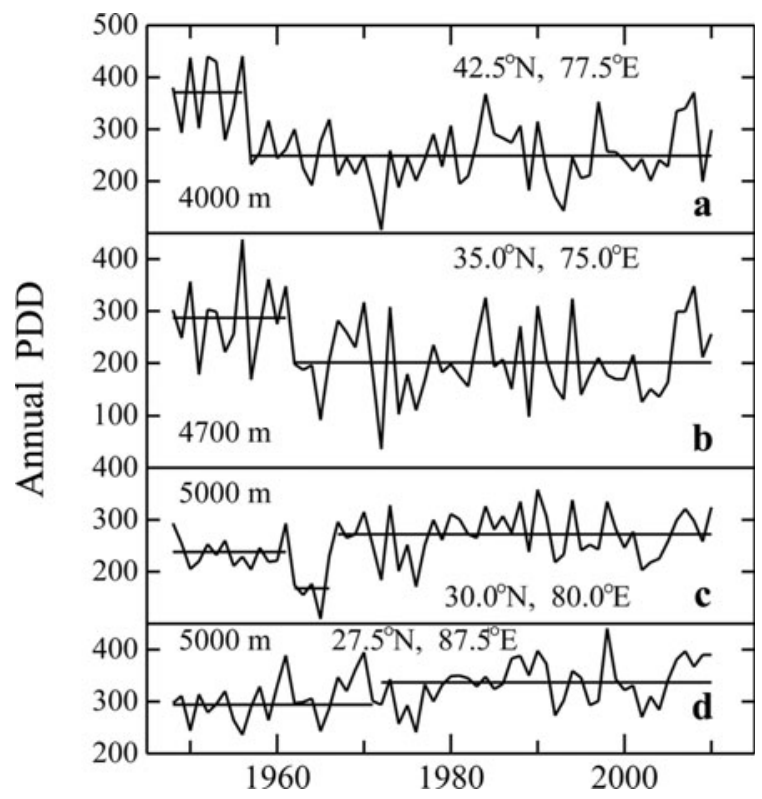

Fig. 5. 1948-2010 variation of annual PDD at indicated altitude at locations (a) T, (b) I, (c) P and (d) K shown in Figures 1 and 2. Piecewise-constant function determined as in Figure 3, except that $p<0.01$ for all pairs of successive stages.

That correlation is often poor between upper-air meteorological conditions and weather station observations does not detract from the utility of the upper-air data in modelling glacier mass balance. The link between upper-air conditions and glacier mass balance might be stronger than between either one of them and conditions at surface weather stations. In the case of Ürümqi glacier No. 1 over 195990, for instance, Cao (1998) found that the strong downward shift of mass balance in 1977 was not accompanied by abrupt changes in the record of either summer temperature or annual precipitation at nearby Daxigou weather station.

Improved correlation of upper-air conditions with mass balance might be a consequence of the glaciers being at high altitude, sensing free-air conditions in the atmosphere. In contrast, weather stations are usually at low altitude in confined valleys, where they are more susceptible to surface effects, such as low clouds and aerosols. Another advantage of using the free-air temperatures is it avoids the need to make assumptions about vertical lapse rates that is required when using data from weather stations.

Whereas reanalysis temperatures are valuable estimators of annual variation in summer balance, reanalysis precipitation values are poor estimators of annual variation in winter balance. Poor correlation of NCEP/NCAR reanalysis precipitation and glacier winter balance on an annual basis might be a reflection of the lower reliability of the reanalysis, as noted by Rupper and Roe (2008). Inaccuracy of annual precipitation values might cancel somewhat when summed over multi-year periods, as suggested by its correlation with multi-year mass balance (Tables 2 and 3).

\section{CONCLUSIONS}

Although the NCEP/NCAR reanalysis lacks fine spatial resolution, it does provide a uniform, homogeneous record of upper-air temperature that has been successfully used to model interannual variation of glacier-wide summer surface

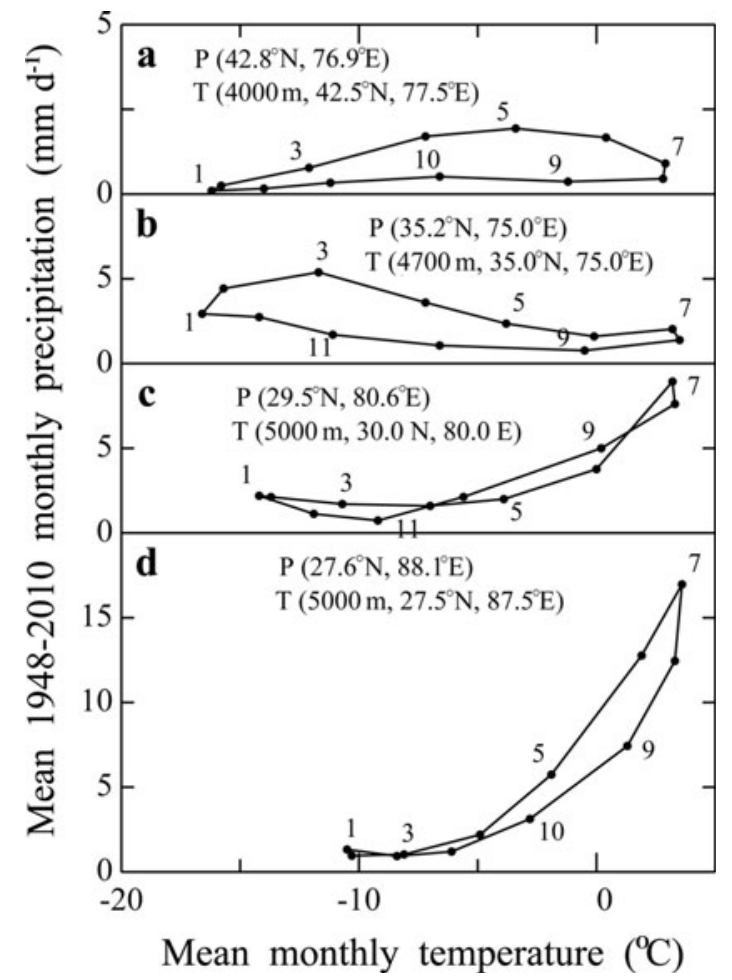

Fig. 6. Seasonal covariance of monthly precipitation, $P\left(\mathrm{~mm} \mathrm{~d}^{-1}\right)$, and temperature, $T\left({ }^{\circ} \mathrm{C}\right)$, at indicated altitude at locations (a) T, (b) I, (c) P and (d) K shown in Figures 1 and 2, all averaged over 19482010. Numbers on the curves indicate the months.

balance, $B_{\mathrm{s}}$, of many glaciers in several other regions. It correlates well at the few glaciers in High Asia where measurements of $B_{\mathrm{s}}$ have been published (Table 1). Of particular note is that cooling in the Tien Shan and western Himalaya after the mid-1960s was accompanied by warming in the rest of the Himalaya (Fig. 5).

In contrast to the utility of the reanalysis temperature in estimating $B_{\mathrm{s}}$, precipitation in that database is not a good estimator of interannual variation of winter surface balance. Over multi-year periods, however, it does correlate well with geodetic measurements of mass balance. Spatial distribution of its 1948-2010 averages (Figs 1 and 2) is, therefore, likely to be more realistic, and similarly the seasonal distribution of those averages (Fig. 6).

According to published geodetic determinations, mean glacier-wide annual surface mass balance, $B_{\mathrm{a}}$, at seven glaciers near Qomolongma (Table 3) declined from an average of $-0.18 \mathrm{~m}$ w.e. in 1971-2002 to $-0.82 \mathrm{mw}$.e. in 2003-07. Between those two periods, there was only a $~ 5 \%$ increase in the number of $5000 \mathrm{~m}$ PDDs, but there was a $\sim 20 \%$ decrease in precipitation. This was also the case at three other glaciers in Nepal, but warming played a stronger role elsewhere. At eight nearby glaciers in the Tien Shan (Table 2) there was a pronounced decline in surface mass balance between 1965-73 and 1974-90 that was accompanied by $\sim 20 \%$ decrease in precipitation and $\sim 10 \%$ increase in $3500 \mathrm{~m}$ PDD, near the middle of the altitude range of the glaciers.

The small and declining number of traditional massbalance programs makes calibrating mass-balance models difficult. Because the effects of meteorological variables on mass-balance processes are known in principle, however, it 
is worth considering spatial and temporal variations of those variables. They are described here over $25-50^{\circ} \mathrm{N}, 60-100^{\circ} \mathrm{E}$ for 1948-2010. In the likely absence of rejuvenated programs, future variations of the variables, along with known approximate relations between them and surface mass balance, can create a rough proxy for variation of mass balance.

\section{ACKNOWLEDGEMENTS}

Comments by $\mathrm{H}$. Conway and $\mathrm{B}$. Hallet improved the reasoning and writing. I thank $\mathrm{H}$. Greenberg for superb preparation of Figures 1 and 2. Comments by G. Cogley and an anonymous reviewer led to a much better paper. Scientific Editor V. Radic and Chief Editor G. Flowers made invaluable suggestions for further improvement. Support from US National Science Foundation grant EAR 095-2352 and from the US Agency for International Development CHARIS project is deeply appreciated.

\section{REFERENCES}

Aizen VB, Aizen EM, Melack JM and Dozier J (1997) Climatic and hydrological change in the Tien Shan, central Asia. J. Climate, 10(6), 1393-1404

Barnett TP, Adam JC and Lettenmaier DP (2005) Potential impacts of a warming climate on water availability in snow-dominated regions. Nature, 438(7066), 303-309 (doi: 10.1038/ nature04141)

Berthier E, Arnaud Y, Kumar R, Ahmad S, Wagnon P and Chevallier P (2007) Remote sensing estimates of glacier mass balances in the Himachal Pradesh (Western Himalaya, India). Remote Sens. Environ., 108(3), 327-338 (doi: 10.1016/ j.rse.2006.11.017)

Bhutiyani MR (1999) Mass-balance studies on Siachen Glacier in the Nubra Valley, Karakoram Himalaya, India. J. Glaciol., 45(149), 112-118

Bolch T (2007) Climate change and glacier retreat in northern Tien Shan (Kazahkstan/Kyrgyzstan) using remote sensing data. Global Planet. Change, 56(1-2), 1-12 (doi: 10.1016/j.gloplacha. 2006.07.009)

Bolch T, Pieczonka T and Benn DI (2011) Multi-decadal mass loss of glaciers in the Everest area (Nepal Himalaya) derived from stereo imagery. Cryosphere, 5(2), 349-358 (doi: 10.5194/tc-5349-2011)

Bolch T and 10 others (2012) The state and fate of Himalayan glaciers. Science, 336(6079), 310-314 (doi: 10.1126/ science.1215828)

Bookhagen B and Burbank DW (2010) Toward a complete Himalayan hydrological budget: spatiotemporal distribution of snowmelt and rainfall and their impact on river discharge. J. Geophys. Res., 115(F3), F03019 (doi: 10.1029/2009JF001426)

Braithwaite RJ (1981) On glacier energy balance, ablation, and air temperature. J. Glaciol., 27(97), 381-391

Cao MS (1998) Detection of abrupt changes in glacier mass balance in the Tien Shan Mountains. J. Glaciol., 44(147), 352-358

Cogley JG (2008) Records of glacier mass balance. Trent Technical Note 2008-1. Department of Geography, Trent University, Peterborough

Cogley JG (2011) Present and future states of Himalaya and Karakoram glaciers. Ann. Glaciol., 52(59), 69-73 (doi: 10.3189/ 172756411799096277)

Fountain AG and Tangborn W (1985) The effects of glaciers on streamflow variations. Water Resour. Res., 21(4), 579-586

Fowler HJ and Archer DR (2006) Conflicting signals of climatic change in the Upper Indus Basin. J. Climate, 19(17), 4276-4293 (doi: 10.1175/JCLI3860.1)
Frauenfeld OW, Zhang T and Serreze MC (2005) Climate change and variability using European Centre for Medium-Range Weather Forecasts reanalysis (ERA-40) temperatures on the Tibetan Plateau. J. Geophys. Res., 110(D2) D02101 (doi: 10.1029/2004JD005230)

Fujita K and Nuimura T (2011) Spatially heterogeneous wastage of Himalayan glaciers. Proc. Natl Acad. Sci. USA (PNAS), 108(34), 14 011-14 014 (doi: 10.1073/pnas.1106242108)

Gardelle J, Berthier E and Arnaud Y (2012) Slight mass gain of Karakoram glaciers in the early 21 st century. Nature Geosci., 5(5), 322-325 (doi: 10.1038/ngeo1450)

Han T, Ding Y, Ye B, Liu S and Jiao K (2006) Mass-balance characteristics of Ürümqi glacier No. 1, Tien Shan, China. Ann. Glaciol., 43, 323-328 (doi: 10.3189/172756406781811961)

Hewitt K (2005) The Karakoram anomaly? Glacier expansion and the 'elevation effect', Karakoram Himalaya. Mt. Res. Dev., 25(4), $332-340$

Hirabayashi Y, Döll Pand Kanae S (2010) Global scale modeling of glacier mass balances for water resources assessments: glacier mass changes between 1948 and 2006. J. Hydrol., 390(3-4), 245-256 (doi: 10.1016/j.jhydrol.2010.07.001)

Hock R (2003) Temperature index melt modelling in mountain areas. J. Hydrol., 282(1-4), 104-115 (doi: 10.1016/S00221694(03)00257-9)

Immerzeel WW, Van Beeke LPH and Bierkens MFP (2010) Climate change will affect the Asian water towers. Science, 328(5984), 1382-1385

Jacob T, Wahr J, Pfeffer WT and Swenson S (2012) Recent contributions of glaciers and ice caps to sea level rise. Nature, 482(7386), 514-518 (doi: 10.1038/nature10847)

Jing Z, Jiao K, Yao T, Wang N and Li Z (2006) Mass balance and recession of Ürümqi glacier No. 1, Tien Shan, China, over the last 45 years. Ann. Glaciol., 43, 214-217 (doi: 10.3189/ 172756406781811899)

Kalnay E and 21 others (1996) The NCEP/NCAR 40-year reanalysis project. Bull. Am. Meteorol. Soc., 77(3), 437-471 (doi: 10.1175/ 1520-0477(1996)077<0437:TNYRP $>2.0$. CO;2)

Kargel JS, Cogley JG, Leonard GJ, Haritashya UK and Byers A (2011) Himalayan glaciers: the big picture is a montage. Proc. Natl Acad. Sci. USA (PNAS), 108(36), 14709-14710 (doi: 10.1073/pnas.1111663108)

Kaser G, Grosshauser M and Marzeion B (2010) Contribution potential of glaciers to water availability in different climate regimes. Proc. Natl Acad. Sci. USA (PNAS), 107(47), $20223-$ 20227 (doi: 10.1073/pnas.1008162107)

Kayastha RB, Ageta Y, Nakawo M, Fujita K, Sakai A and Matsuda Y (2003) Positive degree-day factors for ice ablation on four glaciers in the Nepalese Himalayas and Qinghai-Tibetan Plateau. Bull. Glaciol. Res., 20, 7-14

Kistler R and 12 others (2001) The NCEP/NCAR 50-year reanalysis: monthly means CD-ROM and documentation. Bull. Am. Meteorol. Soc., 82(2), 247-267

Ohmura A (2001) Physical basis for the temperaturebased melt-index method. J. Appl. Meteorol., 40(4), 753-761 (doi: 10.1175/1520-0450(2001)040<0753:PBFTTB > 2.0.CO;2)

Pai DS and Rajeevan M (2007) Indian summer monsoon onset: variability and prediction. National Climate Centre, Indian Meteorological Department, Pune

Putkonen JK (2004) Continuous snow and rain data at 500 to $4400 \mathrm{~m}$ altitude near Annapurna, Nepal, 1999-2001. Arct. Antarct. Alp. Res., 36(2), 244-248

Quincey DJ, Copland L, Mayer C, Bishop M, Luckman A and Beló M (2009) Ice velocity and climate variations for Baltoro Glacier, Pakistan. J. Glaciol., 55(194), 1061-1071 (doi: 10.3189/ 002214309790794913)

Rasmussen LA and Conway H (2003) Using upper-air conditions to estimate South Cascade Glacier (Washington, USA) summer balance. J. Glaciol., 49(166), 456-462 (doi: 10.3189/ 172756503781830629) 
Ren J, Jing Z, Pu J and Qin X (2006) Glacier variations and climate change in the central Himalaya over the past few decades. Ann. Glaciol., 43, 218-222 (doi: 10.3189/172756406781812230)

Rupper S and Roe G (2008) Glacier changes and regional climate: a mass and energy balance approach. J. Climate, 21(20), 5384-5401 (doi: 10.1175/2008JCLI2219.1)

Shrestha AB, Wake CP, Dibb JE and Mayewski PA (2000) Precipitation fluctuations in the Nepal Himalaya and its vicinity and relationship with some large scale climatological parameters. Int. J. Climatol., 20(3), 317-327

Thayyen RJ and Gergan JT (2010) Role of glaciers in watershed hydrology: a preliminary study of a 'Himalayan catchment'. Cryosphere, 4(1), 115-128
World Glacier Monitoring Service (WGMS) (2008a) Global glacier changes: facts and figures, eds Zemp $M$, Roer I, Kääb A, Hoelzle M, Paul F and Haeberli W. World Glacier Monitoring Service/United Nations Environment Programme, Zürich

WGMS (2008b) Fluctuations of glaciers 2000-2005 (Vol. IX), eds Haeberli W, Zemp M, Kääb A, Paul F and Hoelzle M, ICSU/ IUGG/UNEP/UNESCO/WMO. World Glacier Monitoring Service, Zürich

Zhang Y, Liu S, Xie C and Ding Y (2006) Application of a degreeday model for the determination of contributions to glacier meltwater and runoff near Keqicar Baqi glacier, southwestern Tien Shan. Ann. Glaciol., 43, 280-284 (doi: 10.3189/ 172756406781812320) 